\title{
PENENTUAN UPAH MINIMUM KOTA BERDASARKAN TINGKAT INFLASI MENGGUNAKAN BACKPROPAGATION NEURAL NETWORK (BPNN)
}

\author{
Ervin Yohannes ${ }^{1}$, Wayan Firdaus Mahmudy ${ }^{2}$, Asyrofa Rahmi ${ }^{3}$ \\ 1,2,3,4 Magister Ilmu Komputer, Fakultas Ilmu Komputer, Universitas Brawijaya \\ Email: 1ervinyohannes@yahoo.com, ${ }^{2}$ wayanfm@ub.ac.id, asyrofarahmi@gmail.com
}

(Naskah masuk: 2 Agustus 2015, diterima untuk diterbitkan: 5 September 2015)

\begin{abstract}
Abstrak
Upah Minimum Kota (UMK) adalah sebuah standardisasi upah atau gaji karyawan atau pegawai untuk diterapkan diperusahaan baik itu BUMN, BUMS, maupun perusahaan lain yang berskala besar. Faktor yang mempengaruhi UMK sangat banyak dan beragam salah satunya adalah rata-rata inflasi pengeluaran dimana terdapat 8 kategori yang dipakai. Tulisan ini memaparkan penggunaan Backpropagation Neural Network (BPNN) untuk memprediksi besarnya UMK. Pada tahap uji coba data dibagi menjadi dua bagian yaitu data latih dan data uji, dimana data latih digunakan untuk mencari jumlah iterasi, jumlah hidden layer, dan nilai learning rate yang optimal. Pengujian data latih memberikan hasil yakni jumlah iterasi optimal diperoleh pada saat iterasi 80, sedangkan untuk jumlah hidden layer yang optimal adalah sebanyak satu hidden layer dan untuk nilai learning rate optimal yakni pada saat bernilai 0.8. Semua variabel yang diperoleh dikatakan optimal karena memiliki rata-rata MSE paling kecil dibandingkan dengan data lainnya. Hasil yang diperoleh saat data uji dengan menggunakan iterasi, jumlah hidden layer, dan nilai learning rate yang optimal didapatkan hasil MSE sebesar 0.07280534710552478 .
\end{abstract}

Kata kunci: UMK, Inflasi, Backpropagation Neural Network (BPNN), MSE

\begin{abstract}
State Minimum Wage (SMW) is a standardization of wages or salary of the employee applied in the company's State-Owned Enterprises, Private Enterprises, and other large-scale enterprise. Factors that affect SMWs are numerous and varied one of which is the average rate of inflation expenditure where there are eight categories used. This paper explained Backpropagation Neural Network (BPNN) method to predict the magnitude of SMW. In the trial phase, BPNN data is divided into two namely the training data and test data, where the training data is used to find the number of iterations, the number of hidden layer, and the value of the optimal learning rate. From the test results obtained training data at the time optimal number of iterations 80 iterations, while for the optimal number of hidden layer is as much as one hidden layer and to value learning optimal rate at the time is worth 0.8. All variables were obtained said to be optimal because the average MSE is small compared to other data. The results obtained when the test data by using iterations, the number of hidden layer, learning rate and the optimal value is obtained MSE of 0.07280534710552478.
\end{abstract}

Keywords: UMK, Inflasi, Backpropagation Neural Network (BPNN), MSE

\section{PENDAHULUAN}

Kebijakan upah minimum adalah sistem penggajian yang banyak diterapkan hampir di semua negara, yang mana berdasarkan dua sisi. Sisi pertama, gaji minimum adalah alat perlindungan bagi karyawan atau pegawai untuk mempertahankan nilai gaji yang diterima agar tidak turun guna untuk memenuhi kebutuhan sehari-hari. Sedangkan untuk sisi kedua, adalah alat untuk perlindungan bagi perusahaan agar bisa mempertahankan produktivitas karyawan atau pegawai. Mayoritas tingkat gaji minimum rata-rata pertahun meningkat secara signifikan secara nasional (Sulistiawati, 2012). Lengkapnya masalah tentang gaji minimium menjadi penyebab terjadinya perbedaan antara pencari kerja dan peluang kerja sehingga jumlah pengangguran meningkat dan menyebabkan jumlah investasi berubah. Jumlah pengangguran dan investasi menjadi masalah utama dalam jangka pendek maupun panjang. Pengangguran berhubungan dengan pencari kerja dan peluang kerja yang ada yang mana kebanyakan terdapat perbedaan yang begitu besar (Anggrainy, 2013).

Pengembangan industri dari waktu ke waktu mempunyai tujuan agar dapat menyerap pencari kerja yang semakin tinggi dengan semakin tinggi meningkatnya laju pertumbuhan penduduk. Teori industri secara aktual sangat luas konsepnya, yaitu dimulai dari memproses bahan mentah menjadi barang / bahan jadi. Mengenai investasi, ini sangat bergantung pada peluang kerja dan penghasilan. Besarnya investasi akan mempengaruhi besarnya pencari kerja. Secara teori, nilai investasi semakin besar maka semakin besar pula pencari kerja. Gaji juga memiliki efek pada peluang kerja. Gaji yang ditetapkan semakin tinggi akan mempengaruhi biaya 
produksi meningkat, sehingga harus melakukan efisiensi, dimana pencari kerja dikurangi oleh perusahaan, yang berefek peluang kerja menjadi kecil (Lestari, 2012).

Pada penelitian (Angga, 2014) jaringan syaraf tiruan digunakan untuk prediksi status dari permohonan hutang di salah satu perusahaan finance dan backpropagation sebagai prediksi jaminan motor. Selain itu pada (Liu, 2016), kombinasi antara backpropagation neural network (BPPN) dengan empirical mode decomposition (EMD) untuk model baru dari peramalan suhu air. Di paper (Gaxiola, 2015) dipaparkan mengenai perbandingan dari neural network yang ditujukan dengan memperluas 2 tipe bobot fuzzy (NNGT2FW) dengan menghubungkan neural network monolitik (NN) dan neural network dengan interval 2 tipe bobot fuzzy (NNIT2FW) diterangkan. Sebuah studi yang bertujuan membangun model prediksi resiko untuk dukungan tugas dalam kendaraan dengan pengemudi dengan menggunakan dua metode: analisis tugas (TA) dan backpropagation neural networks (BPNNs) telah dijelaskan pada paper $(\mathrm{Ou}, 2013)$. Pada paper (Babkin, 2015) didapatkan nilai minimum error dalam peramalan wilayah pengembangan sosial ekonomi berdasarkan pada neural network menunjukkan derajat tertinggi dari hasil peramalan neural network dibandingkan dengan metode lainnya. Jadi, backpropagation neural network lebih akurat dan hasil yang didapatkan lebih bagus dibandingkan metode lainnya dan data yang dibutuhkan jga tidak harus banyak untuk menggunakan metode ini.

Pada penelitian ini digunakan metode backpropagation neural network untuk memprediksi besarnya Upah Minimum Kota (UMK) berdasarkan inflasi (bahan makanan, pangan, tanggungan, sandang, kesehatan, pendidikan, transportasi, dan umum) menurut kelompok pengeluaran yang ada di Kota Malang data yang didapat diperoleh dari situs http://malangkota.bps.go.id/ dan harapannya penelitian memperoleh hasil yang optimal dalam memprediksi UMK.

\section{BACKPROPAGATION NEURAL NETWORK (BPNN)}

Backpropagation neural network mempunyai kemampuan yang kuat dari interpolasi non-linear. Ini dapat berisi pencerminan pemetaan matematis hukum internal dari data eksperimen. Metode ini secara luas digunakan dalam aplikasi teknik untuk prediksi dan optimalisasi (Yin, 2011). BPNN disusun berdasarkan algoritma descent gradien, yang mana diusulkan oleh Rumelhart dan McClelland. Ini adalah model jaringan banyak layer, yang intinya adalah BPA (Backpropagation algorithm). Dengan interkoneksi yang tepat dari sejumlah node dalam cara yang cocok dan pengaturan bobot untuk menyesuaikan nilai, neural network dapat memperkirakan fungsi nonlinear apapun dengan presisi yang berubah-ubah. BPNN terdiri dari input layer, beberapa hidden layers dan output layer. Tiga layer dalam BPNN digambarkan pada Gambar 1 (Chen, 2013).

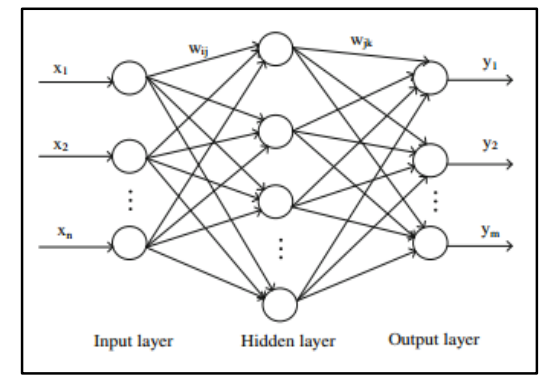

Gambar 1. Arsitektur tiga layer dalam BPNN

Penentuan jumlah lapisan hidden layer dan neuronnya sangat penting serta berpengaruh pada kecepatan serta keakuratan hasil pembelajaran. Penggunaan satu hidden layer mampu menyelesaikan berbagai masalah. Sedangkan penentuan jumlah neuron pada hidden layer harus memenuhi aturan (Heaton, 2005):

a. Berada dalam interval jumlah neuron input maupun output layer

b. Jumlah neuron pada hidden layer adalah $2 / 3$ dari jumlah neuron pada input layer, ditambah dengan jumlah neuron pada output layer

c. Jumlah neuron pada hidden layer kurang dari dua kali jumlah neuron pada input layer.

Normalisasi data adalah suatu proses yang menentukan nilai sehingga nilai berada pada range tertentu. Proses ini bertujuan untuk menghasilkan data yang baik dan berkualitas. Metode normalisasi data adalah minimum-maximum. Adapun rumus matematika untuk metode ini.

$$
x^{\prime}=\left(0.8 x \frac{x-\min \text { value }}{\max \text { value }-\min \text { value }}\right)+0.1
$$

Keterangan :

$$
\begin{array}{ll}
x & =\text { data } \\
x & \\
\text { min value } & =\text { hasil normalisasi } \\
\text { max value } & =\text { nilai minimum } \\
\text { Fungsimaksimum }
\end{array}
$$

Fungsi sigmoid digunakan untuk memenuhi beberapa syarat kontinu, terdeferensial dengan mudah dan merupakan fungsi yang tidak naik turun. Rumus fungsi aktivasi :

$$
\begin{aligned}
& y=\frac{1}{1+e^{-x}} \\
& y^{\prime}=f(x)(1-f(x))
\end{aligned}
$$

Keterangan :

$e \quad=$ bilangen eural yaitu 2.71828

$x=$ hasil penjumlahan dari sinyal - sinyal input

$y=$ = fungsi untuk mengaktivasi nilai $\mathrm{x}$

$y^{\prime} \quad=$ turunan dari $\mathrm{f}(\mathrm{x})$

Dalam metode backpropagation neural network terdapat 3 fase penting yang perlu diselesaikan terlebih dahulu. Fasenya dalah fase feedforward, back propagation, dan weight update. Dalam fase feedforward dibagi menjadi beberapa bagian. Setiap 
unit masukan $\left(\mathrm{x}_{\mathrm{i}}, \mathrm{i}=1, \ldots \mathrm{n}\right)$ menerima sinyal dan meneruskan $\mathrm{x}_{\mathrm{i}}$ ke unit - unit lapisan tersembunyi. Hitung semua keluaran pada unit lapisan tersembunyi $\mathrm{z}_{\mathrm{j}}(\mathrm{j}=1,2, \ldots, \mathrm{p})$.

$z_{-}$net $_{j}=v_{j 0}+\sum_{i=1}^{n} x_{i} \cdot v_{j i}$

Keterangan :

Z_netj = nilai untuk menghitung hidden layer

$V_{j 0} \quad=$ bobot bias antara input layer dengan hidden layer $(\mathrm{vj} 0=0)$

$x_{i} \quad=$ nilai input layer ke $\mathrm{i}$

$\mathrm{v}_{\mathrm{ji}} \quad=$ bobot antara input layer dengan hidden layer

$z_{j}=f\left(z_{-} n e t_{j}\right)=\frac{1}{1+\exp ^{\left(-z_{-} n e t_{j}\right)}}$

Keterangan :

$z_{j} \quad=$ nilai hidden layer

$z_{-} n e t_{j} \quad=$ nilai untuk menghitung

hitung semua keluaran pada unit $\mathrm{y}_{\mathrm{k}}(\mathrm{k}=1,2, \ldots, \mathrm{m})$

$y_{-} n e t_{k}=w_{k 0}+\sum_{j=1}^{p} z_{j} \cdot w_{k j}$

Keterangan :

$y_{-} n e t_{k}=$ net masukan unit $\mathrm{k}$

$w_{k 0} \quad=$ nilai penimbang sambungan pada bias untuk unit $\mathrm{y}_{\mathrm{k}}\left(\mathrm{w}_{k 0}=0\right)$

$z_{j} \quad=$ nilai aktivasi dari unit $\mathrm{z}_{\mathrm{j}}$

$w_{k j} \quad=$ nilai penimbang sambungan dari $\mathrm{z}_{\mathrm{ij}} \mathrm{ke}$ unit $\mathrm{y}_{\mathrm{k}}$

$y_{k}=f\left(y_{-} n e t_{k}\right)=\frac{1}{1+e x p\left(-y_{-} \text {net }_{k}\right)}$

Keterangan :

$y_{k} \quad=$ unit $\mathrm{ke}-\mathrm{k}$ pada lapisan keluaran

$y_{-}$net $_{k}=$ net masukan unit $\mathrm{k}$

fase dalam backpropagation sama halnya dengan fase sebelumnya juga dibagi menjadi beberapa bagian. Hitung faktor $\delta$ unit keluaran berdasarkan kesalahan pada setiap unit keluaran $\mathrm{y}_{\mathrm{k}}$ dimana $\mathrm{k}=$ $1,2, \ldots, \mathrm{m}$

$\delta_{k}=\left(t_{k}-y_{k}\right) f^{\prime}\left(y_{-} n e t_{k}\right)=\left(t_{k}-y_{k}\right) y_{k}\left(1-y_{k}\right)$

(8)

Keterangan :

$\delta_{k} \quad=$ faktor pengaturan nilai penimbang sambungan pada lapisan keluaran

$t_{k} \quad=$ nilai target data

$y_{k} \quad=$ unit $\mathrm{ke}-\mathrm{k}$ pada lapisan keluaran

$y_{\_} n e t_{k}=$ net masukan unit $\mathrm{k}$

$\delta_{\mathrm{k}}$ merupakan unit kesalahan yang dipakai dalam perubahan bobot layer dibawahnya. Hitung perubahan bobot $\mathrm{w}_{\mathrm{kj}}$ dengan percepatan $\alpha$

$\Delta w_{k j}=\alpha \cdot \delta_{k} \cdot z_{j}$

Keterangan :

$\Delta w_{k j}=$ selisih antara $\mathrm{w}_{\mathrm{kj}}\{\mathrm{t}\}$ dengan $\mathrm{w}_{\mathrm{kj}}(\mathrm{t}+1)$

$\alpha \quad=$ learning rate $0<\alpha<1$

$\delta_{k} \quad=$ faktor pengaturan nilai penimbang sambungan pada lapisan keluaran

$z_{j} \quad=$ nilai aktivasi dari unit $\mathrm{z}_{\mathrm{j}}$

dimana $\mathrm{k}=1,2, . ., \mathrm{m}$ dan $\mathrm{j}=0,1, \ldots \mathrm{p}$. Menghitung faktor $\delta$ layer tersembunyi berdasarkan kesalahan pada setiap layer tersembunyi $\mathrm{z}_{\mathrm{j}}$, dimana $\mathrm{j}=1,2, \ldots, \mathrm{p}$ $\delta_{-}$net $_{j}=\sum_{k=1}^{m} \delta_{k} \cdot w_{k j}$

Keterangan :

$\delta \_n e t_{j}=$ nilai untuk menghitung kesalahan di hidden layer

$\delta_{k} \quad=$ faktor pengaturan nilai penimbang

sambungan pada lapisan keluaran

$w_{k j} \quad=$ nilai penimbang sambungan dari $\mathrm{z}_{\mathrm{ij}} \mathrm{ke}$ unit $\mathrm{y}_{\mathrm{k}}$

faktor $\delta$ layar tersembunyi :

$\delta_{j}=\delta_{-} n e t_{j} \cdot f^{\prime}\left(z_{-} n e t_{j}\right)=\delta_{-} n e t_{j} \cdot z_{j} \cdot\left(1-z_{j}\right)(11)$

keterangan :

$\delta$ net $_{j} \quad=$ nilai untuk menghitung kesalahan di hidden layer

$z \_n e t_{j} \quad=$ net masukan untuk unit $\mathrm{j}$

$z_{j} \quad=$ nilai aktivasi dari unit $\mathrm{z}_{\mathrm{j}}$

Hitung perubahan bobot vji dengan menggunakan rumus

$\Delta v_{j i}=\alpha \cdot \delta_{j} \cdot x_{i}$

Keterangan :

$\Delta v_{j i} \quad=$ selisih antara $\mathrm{v}_{\mathrm{ij}}(\mathrm{t})$ dengan $\mathrm{v}_{\mathrm{ij}}(\mathrm{t}+1)$

$\alpha \quad=$ learning rate $0<\alpha<1$

$\delta_{j} \quad=$ faktor pengaturan nilai penimbang sambungan pada lapisan tersembunyi

$x_{i} \quad=$ unit ke $-\mathrm{i}$ pada lapisan masukan

dimana $j=1,2, \ldots, p$ dan $i=0,1, \ldots, n$

Dan untuk proses ketiga yaitu weight update pertama adalah menghitung perubahan bobot garis yang menuju unit keluaran.

$w_{k j}($ baru $)=w_{k j}(\operatorname{lama})+\Delta w_{k j}$

Keterangan :

$w_{k j} \quad=$ nilai penimbang sambungan dari $\mathrm{z}_{\mathrm{ij}} \mathrm{ke}$ unit $\mathrm{y}_{\mathrm{k}}$

$\Delta w_{k j} \quad=$ selisih antara $\mathrm{w}_{\mathrm{kj}}\{\mathrm{t}\}$ dengan $\mathrm{w}_{\mathrm{kj}}(\mathrm{t}+1)$

Dimana $\mathrm{k}=1,2, \ldots, \mathrm{m}$ dan $\mathrm{j}=0,1, \ldots, \mathrm{p}$. setelah itu adalah menghitung perubahan bobot garis yang menuju lapisan tersembunyi

$v_{j i}($ baru $)=v_{j i}($ lama $)+\Delta v_{j i}$

Keterangan :

$v_{j i} \quad=$ nilai penimbang sambungan dari unit $\mathrm{x}_{\mathrm{i}}$ ke unit $\mathrm{z}_{\mathrm{i}}$

$\Delta v_{j i} \quad=$ selisih antara $\mathrm{v}_{\mathrm{ij}}(\mathrm{t})$ dengan $\mathrm{v}_{\mathrm{ij}}(\mathrm{t}+1)$

Dimana $\mathrm{j}=1,2, \ldots, \mathrm{p}$ dan $\mathrm{i}=0,1, \ldots, \mathrm{n}$

Pada backpropagation neural network sebelum melanjutkan proses ke-2 maka harus menghitung terlebih dahulu persamaan $1-14$ kemudian baru dapat berlanjut ke proses berikutnya.

Mean square error (MSE) merupakan metode yang digunakan untuk menguji kesalahan pada sistem. Rumus matematika untuk MSE

$M S E=\frac{1}{k} \sum_{k=1}^{n}\left(y_{k}-t_{k}\right)^{2}$

Dimana :

$n \quad=$ jumlah data

$y_{k} \quad=$ nilai output data

$t_{k} \quad=$ nilai target data

Dalam pengujian backpropagation neural network, ada proses yang dinamakan denormalisasi. Denormalisasi adalah sebuah proses yang mengubah nilai hasil normalisasi ke data asli. Rumus matematika untuk denormalisasi adalah :

$x^{\prime \prime}=\frac{(\max \text { value }-\min \text { value }) *\left(x^{\prime}-0.1\right)}{0.8}+\min$ value $(16)$

Dimana :

Max value = nilai maksimum 
Min value = nilai minimum

$x^{\prime \prime} \quad=$ hasil denormalisasi

\section{METODE}

Dalam penelitian ini digunakan data yang diperoleh dari situs balai pusat statistik kota malang yang terdiri dari data UMK dan data rata-rata inflasi yang ada pada tahun 2005 - 2014. Data rata-rata inflasi terdapat 8 kategori yang dikelompokkan. Adapun data UMK yang digunakan juga sebagai data output dapat dilihat pada Tabel 1.

Tabel 1. Data UMK kota Malang dari tahun 2005 2014

\begin{tabular}{cc}
\hline $\begin{array}{c}\text { Perkembangan upah minimum kota (UMK) Kota } \\
\text { malang (Rupiah), 2005-2014 }\end{array}$ \\
\hline Tahun & Besarnya UMK \\
\hline 2005 & 575.000 \\
2006 & 681.000 \\
2007 & 769.000 \\
2008 & 802.941 \\
2009 & 945.373 \\
2010 & 1.006 .263 \\
2011 & 1.079 .887 \\
2012 & 1.132 .254 \\
2013 & 1.340 .300 \\
2014 & 1.587 .000 \\
\hline
\end{tabular}

Untuk besarnya rata - rata inflasi, dimana terdapat 8 kategori yang digunakan dan sebagai input. Unuk kategori $1(x)$ adalah rata - rata inflasi dari bahan makanan, kategori $2(x 2)$ adalah rata rata inflasi dari makanan jadi, minuman, rokok, dan tembakau, kategori $3(x 3)$ adalah rata- rata inflasi dari perumahan, air, listrik, gas, dan bahan bakar, kategori $4(x 4)$ adalah rata - rata inflasi dari sandang, kategori $5(x 5)$ adalah rata - rata inflasi dari kesehatan, kategori $6(x 6)$ adalah rata - rata inflasi dari pendidikan, rekreasi, dan olahraga, kategori 7 $(x 7)$ adalah rata - rata inflasi dari transport, komunikasi, dan jasa keuangan, kategori $8(x 8)$ adalah rata - rata inflasi umum dan hasilnya ditunjukkan oleh Tabel 2 berikut ini.

Tabel 2. Data rata - rata inflasi kota Malang dari tahun $2005-2014$

\begin{tabular}{cl}
\hline \multicolumn{2}{c}{ Inflasi kota Malang menurut kelompok pengeluaran dari } \\
tahun 2005 - 2014 \\
\hline Tahun & \multicolumn{1}{c}{ Rata - rata inflasi dengan 8 kategori } \\
\hline 2005 & $\begin{array}{l}9.20,10.20,16.74,7.70,5.72,8.63,39.89, \\
\\
15.74\end{array}$ \\
2006 & $12.13,4.35,4.14,9.66,3.93,8.92,1.27,5.92$ \\
2007 & $12.09,2.95,4.49,12.78,7.48,5.70,0.84,5.93$ \\
2008 & $16.32,13.36,9.04,8.90,8.39,4.37,6.82,10.49$ \\
2009 & $4.74,7.39,1.28,5.86,2.00,5.85,-1.45,3.39$ \\
2010 & $15.27,7.28,2.13,4.33,3.49,9.17,1.03,6.70$ \\
2011 & $6.03,3.56,2.32,7.10,1.94,8.20,1.20,4.05$ \\
2012 & $5.22,5.87,2.38,4.96,1.59,6.74,4.37,4.60$ \\
2013 & $13.17,4.47,5.72,0.66,1.74,1.07,15.31,7.92$ \\
2014 & $6.91,8.19,6.84,3.70,6.32,2.92,15.17,8.14$ \\
\hline
\end{tabular}

Setelah itu adalah proses normalisasi data rata rata inflasi dengan data UMK dengan menggunakan metode minimum - maximum. Salah satu hasil dari normalisasi data yang diperoleh dari data rata - rata inflasi dan UMK dengan menggunakan Persamaan 1 ditunjukkan pada Tabel 3.

Tabel 3. Salah satu hasil normalisasi

\begin{tabular}{cc}
\hline \multicolumn{2}{c}{ Normalisasi } \\
\hline Kategori / Input & Nilai normalisasi input \\
\hline$x 1^{\prime}$ & 0.249914 \\
$x 2^{\prime}$ & 0.50269 \\
$x 3^{\prime}$ & 0.38771 \\
$x 4^{\prime}$ & 0.30062 \\
$x 5^{\prime}$ & 0.656634 \\
$x 6^{\prime}$ & 0.28258 \\
$x 7^{\prime}$ & 0.421626 \\
$x 8^{\prime}$ & 0.407692 \\
\hline Output & Nilai normalisasi output \\
\hline$T^{\prime}$ & 0.9
\end{tabular}

Untuk proses selanjutnya setelah ditemukan nilai normalisasi dari data input dan output maka akan dibentuk nilai input ke hidden dimana nilai yang terbentuk mmpunyai panjang input $x$ hidden. Misalnya hidden $=3$, maka input ke hidden panjangnya adalah $8 \times 3=24$. Pada awalnya ditemukan secara random dengan batas bawah $=-1$, dan batas atas $=1$ serta menggunakan rumus random $x$ (batas atas - batas bawah) + batas bawah. Setelah ditemukan nilai input ke hidden maka dapat mengitung nilai output dari masing - masing hidden dimana panjangnya adalah sejumlah hidden yang diberikan dan untuk menghitungnya dapat menggunakan Persamaan 4. Salah satu hasilnya ditunjukkan oleh Tabel 4.

Tabel 4. Salah satu hasil perhitungan nilai output dari masing - masing hidden

\begin{tabular}{ccc}
\hline \multicolumn{3}{c}{ Nilai output dari masing } \\
\hline Zin1 & Zin2 & Zinsing hidden \\
\hline 0.918633 & 0.764062 & 0.323354 \\
\hline
\end{tabular}

Untuk memperhalus hasil nilai output dari masing - masing hidden dan mengurangi nilai tingkat error maka dapat menggunakan fungsi aktivasi sigmoid biner seperti pada Persamaan 2 yang panjangnya adalah sebanyak panjang nilai yang diperhalus. Hasil yang didapatkan ditunjukkan pada Tabel 5.

Tabel 5. Hasil fungsi aktivasi sigmoid biner

\begin{tabular}{ccc}
\hline \multicolumn{3}{c}{ Fungsi aktivasi sigmoid biner } \\
\hline $\mathbf{Z 1}$ & $\mathbf{Z 2}$ & $\mathbf{Z 3}$ \\
\hline 0.28581 & 0.3183 & 0.4201 \\
\hline
\end{tabular}


Proses berikutnya adalah mencari nilai output yang mana dihasilkan dari hasil random dan caranya sama seperti mencari nilai awal input ke hidden akan tetapi nilai output mempunyai panjang sejumlah hidden yang dimasukkan dengan batas bawah $=0$, dan batas atas $=1$ serta menggunakan rumus random $x$ (batas atas - batas bawah) + batas bawah. Setelah dibentuk atau ditemukan maka akan dihitung nilai output dengan menggunakan Persamaan 6. Jika hidden $=3$ dan output $=1$ maka nilai output yang dihasilkan adalah sebanyak 1 nilai output. Pada Tabel 6 adalah output dan nilai output.

Tabel 6. Hasil output dan nilai output

\begin{tabular}{cccc}
\hline \multicolumn{4}{c}{ Output dan nilai output } \\
\hline Output & & Nilai output \\
\hline w1 & w2 & w3 & Yin \\
\hline 0.89386 & 0.22301 & 0.35644 & 1.325969254 \\
\hline
\end{tabular}

Nilai output yang dihasilkan harus diperhalus menggunakan fungsi aktivasi sigmoid biner seperti pada Persamaan 2. Dari data pada Tabel 6 diperoleh hasil dari fungsi aktivasi sigmoid biner seperti yang ditunjukkan pada Tabel 7.

Tabel 7. Hasil fungsi aktivasi sigmoid biner

\begin{tabular}{c}
\hline Fungsi aktivasi sigmoid biner \\
\hline $\mathbf{Y}$ \\
\hline 0.210498495 \\
\hline
\end{tabular}

Proses selanjutnya menghitung faktor $\delta$ pada neuron output dengan menggunakan Persamaan 8. Hasil dari perhitungan faktor $\delta$ pada neuron output ditunjukkan pada tabel 8 .

Tabel 8. Hasil perhitungan faktor $\delta$ pada neuron output

\begin{tabular}{|c|}
\hline Faktor $\delta$ pada neuron output $Y$ \\
\hline $\bar{\delta}$ \\
\hline 0.114587482 \\
\hline
\end{tabular}

Setelah itu, menghitung suku perubahan bobot dari output ke hidden dengan menggunakan nilai $\alpha=$ 0.64 seperti yang ditunjukkan pada persamaan 9 . Dan hasil dari perhitungannya disajikan pada Tabel 9.

Tabel 9. Hasil perhitungan suku perubahan bobot dari output ke hidden

\begin{tabular}{ccc}
\hline \multicolumn{3}{c}{ Suku perubahan bobot dari output ke hidden } \\
\hline$\Delta \mathbf{w 1}$ & $\Delta \mathbf{w 2}$ & $\Delta \mathbf{w 3}$ \\
\hline 0.020960036 & 0.02334069 & 0.030808373 \\
\hline
\end{tabular}

Persamaan 10 digunakan untuk menjumlahkan kesalahan di hidden neuron. Tabel 10 adalah hasil dari perhitungannya.

Tabel 10. Hasil perhitungan kesalahan di hidden neuron

Penjumlahan kesalahan di hidden neuron

\begin{tabular}{ccc}
\hline $\boldsymbol{\delta} \_$in_1 & $\boldsymbol{\delta} \_$in_2 & $\boldsymbol{\delta} \_$in_3 \\
\hline 0.10242482 & 0.025553637 & 0.040843188 \\
\hline
\end{tabular}

Setelah ditemukan hasil dari perhitungan kesalahan di hidden neuron maka akan dihitung nilai faktor kesalahan $\delta$ di hidden network dengan Persamaan 11. Hasil dari proses ini ditunjukkan pada Tabel 11.

Tabel 11. Hasil perhitungan nilai faktor kesalahan $\delta$ di hidden network

\begin{tabular}{ccc}
\hline \multicolumn{3}{c}{ Hasil perhitungan nilai faktor kesalahan $\boldsymbol{\delta}$} \\
\hline $\boldsymbol{\delta} \mathbf{1}$ & $\boldsymbol{\delta 2}$ & $\boldsymbol{\delta 3}$ \\
\hline 0.0209072 & 0.005544 & 0.00995 \\
\hline
\end{tabular}

proses berikutnya adalah perubahan bobot hidden neuron yang dihitung dengan menggunakan persamaan 12. Setelah semua proses dijalankan dan menghasilkan nilai maka untuk proses selanjutnya adalah weight update yang mana memperbarui bobot baik itu bobot input maupun bobot output yang mana untuk bobot input menggunakan persamaan 13 dan untuk bobot output menggunakan persamaan 14 proses berlanjut kembali mulai dari persamaan 1-12 sampai dengan iterasi yang ditentukan dan untuk iterasi kedua bobot input dan output pada awal iterasi diambil dari bobot terakhir dari iterasi pertama kemudian prosesnya sama dengan proses sebelumnya.

\section{HASIL EKSPERIMEN}

Hasil eksperimen terdiri dari pengujian jumlah hidden layer, pengujian nilai alpha dan pengujian iterasi. Pengujian jumlah iterasi bertujuan untuk mencari jumlah iterasi yang optimal yang digunakan untuk data uji backpropagation neural network nantinya. Jumlah iterasi yang ditetapkan mulai dari iterasi 10 - 100 dengan kelipatan 10, dari hasil tabel 12 iterasi optimal ditunjukkan pada saat iterasi 80 karena rata - rata MSE mulai stabil dan tidak terjadi penurunan atau kenaikan yang signifikan.

Tabel 12. Hasil pengujian jumlah iterasi

\begin{tabular}{lcccccl}
\hline \multirow{6}{*}{ Jumlah Nilai MSE } & \multirow{5}{*}{ Rata-rata } \\
\cline { 2 - 6 } Iterasi & \multicolumn{6}{c}{ MSE } \\
\cline { 2 - 6 } & 1 & 2 & 3 & 4 & 5 & \\
\hline 10 & 0.109 & 0.096 & 0.144 & 0.173 & 0.200 & 0.144 \\
20 & 0.093 & 0.184 & 0.105 & 0.196 & 0.146 & 0.145 \\
30 & 0.105 & 0.130 & 0.168 & 0.111 & 0.108 & 0.124 \\
40 & 0.086 & 0.089 & 0.089 & 0.088 & 0.090 & 0.088 \\
50 & 0.081 & 0.083 & 0.081 & 0.081 & 0.081 & 0.082 \\
60 & 0.081 & 0.078 & 0.077 & 0.094 & 0.082 & 0.083 \\
70 & 0.075 & 0.074 & 0.073 & 0.073 & 0.075 & 0.074 \\
80 & 0.069 & 0.071 & 0.071 & 0.072 & 0.071 & 0.071 \\
90 & 0.069 & 0.069 & 0.070 & 0.071 & 0.067 & 0.069 \\
100 & 0.068 & 0.067 & 0.068 & 0.068 & 0.068 & 0.068 \\
\hline
\end{tabular}




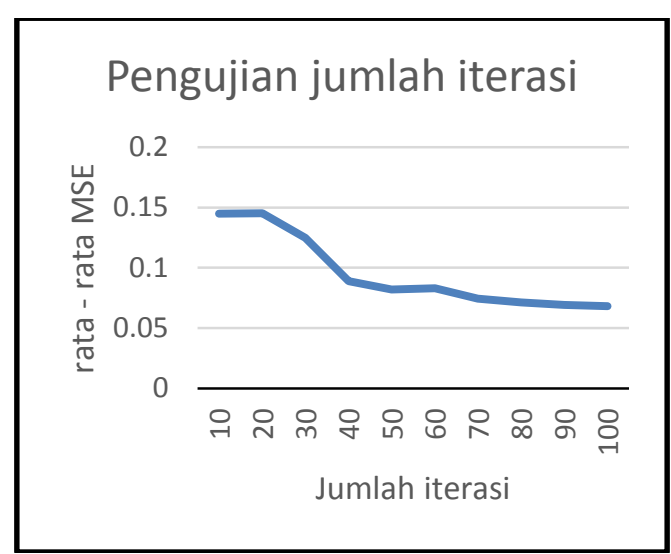

Gambar 2. Grafik pengujian jumlah iterasi

Dari grafik pengujian jumlah iterasi mulai dari pengujian iterasi 80 nilai rata - rata MSE sudah stabil tidak terjadi penurunan atau kenaikan yang signifikan.

Pengujian yang kedua adalah pengujian jumlah hidden layer yang mana seperti dijelaskan pada bab 2 untuk penentuan hidden layer dapat memilih salah satu dari petunjuk yang dijelaskan. Dan pada penelitian ini, dipilih berada dalam interval jumlah neuron input dan output layer. Dan hasilnya ditunjukkan pada tabel 13 .

Tabel 13. Hasil pengujian jumlah hidden layer

\begin{tabular}{lcccccc}
\hline \multirow{2}{*}{$\begin{array}{l}\text { Hidden } \\
\text { layer }\end{array}$} & \multicolumn{5}{c}{ Nilai MSE } & \multirow{2}{*}{$\begin{array}{c}\text { Rata- } \\
\text { rata }\end{array}$} \\
\cline { 2 - 6 } & 1 & 2 & 3 & 4 & 5 & MSE \\
\hline 1 & 0.061 & 0.063 & 0.062 & 0.063 & 0.061 & 0.062 \\
2 & 0.066 & 0.067 & 0.064 & 0.066 & 0.066 & 0.066 \\
3 & 0.071 & 0.069 & 0.071 & 0.069 & 0.069 & 0.070 \\
4 & 0.094 & 0.076 & 0.076 & 0.083 & 0.081 & 0.082 \\
5 & 0.091 & 0.083 & 0.094 & 0.108 & 0.086 & 0.093 \\
6 & 0.097 & 0.137 & 0.100 & 0.139 & 0.229 & 0.140 \\
7 & 0.234 & 0.119 & 0.231 & 0.126 & 0.109 & 0.164 \\
8 & 0.154 & 0.229 & 0.168 & 0.230 & 0.148 & 0.186 \\
9 & 0.235 & 0.233 & 0.229 & 0.192 & 0.218 & 0.221 \\
\hline
\end{tabular}

Dari hasil Tabel 13 karena memakai aturan yang pertama dalam memilih jumlah hidden layer maka rangenya adalah 1-9 dan satu hidden layer dicoba sebanyak 5 kali dan hasil yang optimal diperoleh pada saat hidden layer 1 karena nilai MSE lebih kecil dibandingkan dengan nilai MSE dari jumlah hidden layer lainnya maka nantinya akan digunakan hidden layer 1 untuk data uji backpropagation neural network.

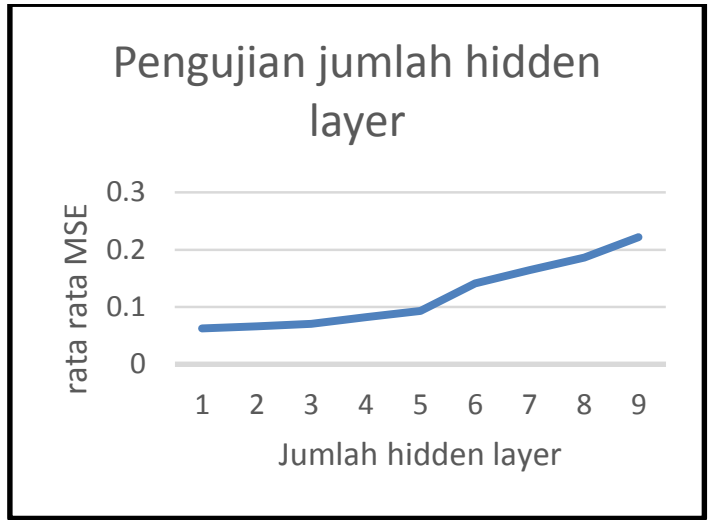

Gambar 3. Grafik pengujian jumlah hidden layer

Dari grafik pengujian jumlah hidden layer pada (Gambar 3) dengan aturan yang pertama dapat dilihat pada saat sistem menggunakan jumlah hidden layer 1 nilai MSE lebih kecil dibandingkan dengan jumlah hidden layer lainnya sehingga untuk data uji menggunakan jumlah hidden layer sebanyak 1 .

Pengujian learning rate sama halnya dengan pengujian pertam dan kedua yang mana bertujuan untuk memperoleh nilai learning rate yang optimal yang nantinya digunakan pada data uji. Untuk hasil dari pengujian nilai learning rate ditunjukkan pada Tabel 14. Dapat dilihat pada learning rate 0.8 selam dilakukan 5 kali percobaan diperoleh nilai rata - rata MSE terkecil dibandingkan dengan nilai learning rate lainnya sehingga nilai learning rate inilah yang akan digunakan sebagai data uji.

Tabel 14. Hasil pengujian learning rate

\begin{tabular}{ccccccc}
\hline \multirow{7}{*}{ nilai } & \multicolumn{5}{c}{ Nilai MSE } \\
\cline { 2 - 5 } Rata-rata \\
\cline { 2 - 5 }$\alpha$ & 1 & 2 & 3 & 4 & 5 & \\
\hline 0.9 & 0.060 & 0.062 & 0.060 & 0.056 & 0.059 & 0.060 \\
0.8 & 0.063 & 0.057 & 0.054 & 0.062 & 0.059 & 0.059 \\
0.7 & 0.060 & 0.061 & 0.062 & 0.062 & 0.061 & 0.061 \\
0.6 & 0.063 & 0.059 & 0.060 & 0.059 & 0.062 & 0.061 \\
0.5 & 0.062 & 0.063 & 0.056 & 0.063 & 0.063 & 0.061 \\
0.4 & 0.062 & 0.060 & 0.060 & 0.060 & 0.060 & 0.060 \\
0.3 & 0.069 & 0.064 & 0.063 & 0.065 & 0.065 & 0.065 \\
0.2 & 0.069 & 0.059 & 0.061 & 0.078 & 0.060 & 0.065 \\
0.1 & 0.058 & 0.058 & 0.054 & 0.055 & 0.058 & 0.057 \\
\hline
\end{tabular}




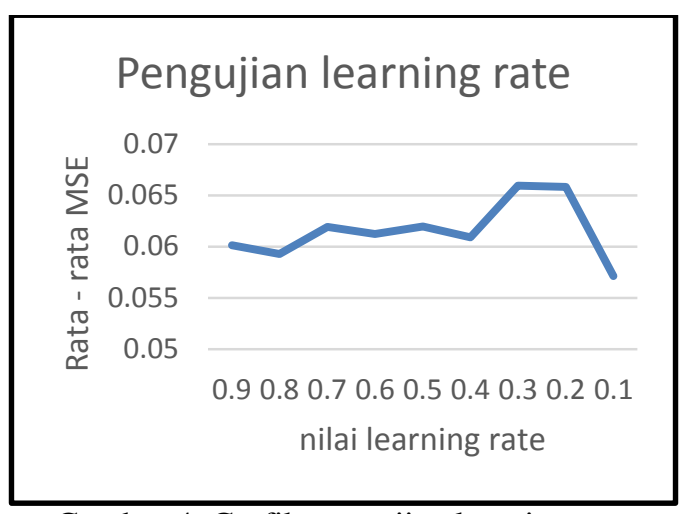

Gambar 4. Grafik pengujian learning rate

Dari grafik pengujian learning rate (Gambar 4) mulai dari $0.9-0.1$ seperti yang ada pada Tabel 14 . Pada learning rate dari range tersebut hampir tidak terjadi penurunan ataupun kenaikan yang signifikan tetapi lebih kearah stabil. Dan dalam penelitian ini digunakan learning rate dengan nilai 0.8 yang mana nantinya akan digunakan untuk data uji.

Setelah semua faktor atau variabel dalam backpropagation neural network dilakukan pengujian mulai dari iterasi, jumlah hidden layer dan learning rate didapatkan hasil optimal dari ketiga variabel dalam backpropagation neural network. Untuk iterasi optimal pada saat iterasi 80, untuk jumlah hidden layer optimal pada saat hidden layer yang digunakan adalah 1, dan untuk learning rate yang optimal pada saat nilainya adalah 0.8 . setelah pengujian dilakukan maka proses selanjutnya adalah data uji. Hasil dari pengujian sistem ditunjukkan pada Tabel 15.

Tabel 15. Hasil pengujian data uji

\begin{tabular}{ccc}
\hline No & UMK & Hasil denormalisasi \\
\hline 1 & 1587000 & 1294363.204 \\
2 & 1340300 & 1289985.273 \\
3 & 1132254 & 1246394.711 \\
4 & 1079887 & 1197060.682 \\
5 & 1006263 & 1283575.989 \\
\hline
\end{tabular}

Dari hasil pengujian data uji pada Tabel 15 diperoleh nilai MSE sebesar 0.07280534710552478.

\section{KESIMPULAN DAN SARAN}

Dari hasil penelitian diperoleh bahwa backpropagation neural network dapat diimplementasikan untuk studi kasus upah minimum kota berdasarkan tingkat inflasi. Dari hasil pengujian data uji diperoleh nilai MSE sebesar 0.07280534710552478 . Penelitian berikutnya dapat menambahkan input dan outputnya. Selain itu, bisa dengan menggunakan dua metode yaitu backpropagation neural network dengan fuzzy.

\section{REFERENSI}

ANGGA, W. W. (2014). Penerapan Algoritma Jaringan Syaraf Tiruan Untuk Prediksi Status Permohonan Hutang
Dan Harga Jaminan Hutang Motor. Skripsi, Fakultas Ilmu Komputer. ANGGRAINY, KHOLIFAH. "Analisis Dampak Kenaikan Upah Minimum Kota (UMK) terhadap Kesempatan Kerja dan Investasi (Studi Kasus pada Kota Malang Periode 2001-2011)". Jurnal ilmiah. Jurusan Ilmu Ekonomi, Fakultas Ekonomi dan Bisnis, Universitas Brawijaya, Malang, 2013

BABKIN, A. V., KARLINA, E. P., and EPIFANOVA, N. S., "Neural Networks as a Tool of Forecasting of Socioeconomic Systems Strategic Development," Procedia - Soc. Behav. Sci., vol. 207, pp. 274-279, 2015.

CHEN H., and ZENG, Z., "Deformation Prediction of Landslide Based on Improved Back-propagation Neural Network," pp. 56-62, 2013.

GAXIOLA, F., MELIN, P., VALDEZ, F., and CASTILLO, O., "Generalized type2 fuzzy weight adjustment for backpropagation neural networks in time series prediction," Inf. Sci. (Ny)., vol. 325, pp. 159-174, 2015

HEATON, JEFF. 2005. Introduction to Neural Network for Java, Second Edition. Heaton Research, Inc. St. Louis.

LESTARI, AYU WAFI. "Pengaruh Jumlah Usaha, Nilai Investasi, dan Upah Minimum terhadap Permintaan Tenaga Kerja pada Industri Kecil dan Menengah di Kabupaten Semarang”. Fakultas Ekonomi, Universitas Diponegoro, Semarang, 2011.

LIU, S., XU, L., and LI, D., "Multi-scale prediction of water temperature using empirical mode decomposition with back-propagation neural networks R," Comput. Electr. Eng., vol. 49, pp. 1-8, 2016.

OU, Y., LIU, Y., and SHIH, F., "Risk prediction model for drivers ' in-vehicle activities - Application of task analysis and back-propagation neural network," Transp. Res. PART F, vol. 18, pp. 8393, 2013

SULISTIAWATI, RINI. "Pengaruh Upah Minimum terhadap Penyerapan Tenaga Kerja dan Kesejahteraan Masyarakat di Provinsi di Indonesia," vol. 8, pp. 195211, 2012.

YIN, F., MAO, H., HUA, L., GUO, W., and SHU, M., "Back Propagation neural network modeling for warpage prediction and optimization of plastic products during injection molding." 